\title{
Discriminant indexes to simplify the differential diagnosis between iron deficiency anemia and thalassemia minor in individuals with microcytic anemia
}

\author{
(DiD Fernando Minervo Pimentel Reis 1 \\ (iD) Raul Ribeiro de Andrade ${ }^{2}$ \\ Célio Fernando de Sousa Rodrigues ${ }^{3}$ \\ (iD) Fabiano Timbó Barbosa ${ }^{4}$
}

\begin{abstract}
1. Farmacêutico-Bioquímico da Unidade de Emergência do Agreste Dr. Daniel Houly. Especialista em Hematologia Clínica, Arapiraca, AL, Brasil 2. Acadêmico de Medicina do Centro Universitário CESMAC, Maceió, AL, Brasil 3. Doutor em Morfologia. Professor titular de Anatomia da Universidade Estadual de Ciências da Saúde de Alagoas, Maceió, AL, Brasil 4. Doutor em Ciências da Saúde. Professor adjunto da disciplina Bases da Técnica Cirúrgica e Anestésica da Universidade Federal de Alagoas, Maceio, AL, Brasil
\end{abstract}

SUMMARY

INTRODUCTION: Microcytic anemias are very common in clinical practice, with iron deficiency anemia (IDA) and thalassemia minor (TT) being the most prevalent. Diagnostic confirmation of these clinical entities requires tests involving iron metabolism profile, hemoglobin electrophoresis, and molecular analysis. In this context, several discriminant indices have been proposed to simplify the differential diagnosis between IDA and TM.

OBJECTIVE: The aim of this paper was to demonstrate the clinical relevance of the use of discriminant indices in individuals with microcytic anemia to simplify the differential diagnosis between iron deficiency anemia and minor thalassemia.

METHODS: A bibliographic and cross-sectional search was performed in the PubMed, SciELO and LILACS databases, using the following descriptors: iron deficiency anemia, thalassemia minor, and differential diagnosis.

RESULTS: More than 40 mathematical indices based on erythrocyte parameters have been proposed in the hematological literature in individuals with microcytosis. Green \& King indexes (IGK), Ehsani index, and erythrocyte count (RBC) had excellent performances, especially when their efficacy was observed in adults and children.

CONCLUSIONS: Confirmatory tests for differential diagnosis between IDA and TM require time-consuming and costly methods. Despite the excellent performances of IGK, Ehsani index, and RBC, none of them presented sufficient sensitivity and specificity to establish a diagnosis. However, they can provide a powerful additional tool for diagnostic simplification between IDA and TM.

KEYWORDS: Anemia, iron-deficiency. Beta-thalassemia. Diagnosis, differential.

\section{INTRODUCTION}

Anemia is a global public health problem that affects both the developed and developing countries and has major consequences for human health, as well as for social and economic development, affecting
$24.8 \%$ of the world population'. Regarding the definition of anemia, most of the medical-scientific studies adopt the criteria proposed by the World Health Organization (WHO), which are: values of circulating 
hemoglobin less than $13 \mathrm{~g} / \mathrm{dL}$ for men (aged 15 years or older); $12 \mathrm{~g} / \mathrm{dL}$ for women (aged 15 years or older, non-pregnant), teenagers, and children aged 12 to 14 years; $11.5 \mathrm{~g} / \mathrm{dL}$ for children aged 5 to 11 years; and 11 $\mathrm{g} / \mathrm{dL}$ for pregnant women and children aged 6 months to 4 years ${ }^{2}$. The most common causes of anemia are iron deficiency (IDA) and thalassemia minor (TM), microcytic anemias characterized by the insufficient synthesis of hemoglobin $(\mathrm{Hb})$ on erythroid precursors, causing a reduction in the mean corpuscular volume (MCV) of erythrocytes ${ }^{3}$.

The causes of IDA include inadequate iron intake, chronic blood loss in the gastrointestinal tract, and prolonged menstrual bleeding. Thalassemia minor (TM) is the result of ineffective erythropoiesis due to an imbalance in the synthesis of globin chains, caused by a genetic abnormality in the hemoglobins ${ }^{4}$.

The differential diagnosis of microcytic anemias is of great clinical relevance since their prognosis and treatment are different. The first step to diagnose microcytic anemias is to analyze blood smear samples and determine the erythrocyte indexes using cell counters $^{5}$. Currently, diagnosis confirmation of these diseases is obtained through exams that assess iron metabolism, hemoglobin electrophoresis, and molecular investigations. All of these methods require significant financial and time resources to confirm the diagnosis. Therefore, with the goal of simplifying the differential diagnosis between IDA and TM, several indexes based on erythrocyte parameters have been suggested ${ }^{6.7}$. The objective of this paper was to demonstrate the clinical relevance of discriminant indexes in individuals with microcytic anemia to simplify the differential diagnosis of iron deficiency anemia and thalassemia minor.

\section{METHODS}

This bibliographic and transversal study was carried out using the descriptors: iron deficiency anemia, thalassemia minor, and differential diagnosis. The descriptors used allowed for a comprehensive search on the subject on the following databases: PubMed, SciELO, and Lilacs. The descriptors used for searching all the databases were: iron deficiency anemia, beta-thalassemia, and differential diagnosis. The inclusion criterion was the presence of the keywords in the title or abstract of the papers, without any date restrictions. There was a restriction on language, and only papers in English or Portuguese were considered.

\section{RESULTS}

A total of 149 articles were obtained through the combined use of the descriptors, of which 106 were irrelevant to the topic or were in other languages. Thus, only 43 articles remained to be analyzed, of which 25 were used in this study, taking into account those that used patients and had more significant statistical results.

\section{DISCUSSION}

Microcytic anemia, characterized by the insufficient synthesis of hemoglobin $(\mathrm{Hb})$ on erythroid precursors and by a reduction in the mean corpuscular volume (MCV) of erythrocytes, is often a consequence of IDA and $\mathrm{TM}^{3.8}$. Other less common causes that should also be considered include chronic disease/ inflammation anemia and sideroblastic anemia ${ }^{5}$.

IDA is a very frequent finding not only in developing countries due to a poor nutritional status, but also in the western world, where women of childbearing age are often diagnosed with IDA due to intermittent blood loss associated with inadequate iron intake ${ }^{8}$. Iron deficiency develops, most of the time, slowly and progressively, and, for didactic purposes, can be divided into three stages: depletion of iron reserves, iron-deficient erythropoiesis, and IDA. Mean values of $\mathrm{Hb}$ of $10.0 \mathrm{~g} / \mathrm{dL}$ (9.3 to 10.7), MCV of $73 \mathrm{fL}$ (67 to 76), mean corpuscular hemoglobin (MCH) of $22.7 \mathrm{pg}(20.8$ to 24.1), and Red Blood Distribution Width (RDW) of $17.9 \%$ (16.6 to 19.4 ) are usually found. The erythrocyte, Red Blood Cell (RBC), count is usually normal or decreased, and the reticulocyte count is normal or reduced $^{5,6,9}$.

Thalassemia, traditionally, is highly prevalent in the Mediterranean region, Middle East countries, the Arabian Peninsula, and Southeast Asia, but population migration has currently spread the genes of thalassemia almost throughout the world ${ }^{8}$. Thalassemias are inherited anemias caused by a partial or complete deficiency of globin chain synthesis and are the most common genetic disorders worldwide, constituting a major public health problem ${ }^{10}$. TM is a clinical definition applied to heterozygous, asymptomatic patients. Its most common types are alpha thalassemia minor and beta-thalassemia minor, in which the subunits of alpha-globin and beta-globin are decreased, respectively ${ }^{11}$. Mean values of $\mathrm{Hb}$ of $10.9 \mathrm{~g} / \mathrm{dL}$ (10.5 to 11.8), MCV of $63.8 \mathrm{fL}$ (61.6 to 68.5), MCH of $20.4 \mathrm{pg}$ (19.7 to 21.6), and RDW of $15.9 \%$ (15.3 
to 16.9) are generally found in both alpha and beta TM. RBC is usually increased and the reticulocyte count is normal or increased ${ }^{5,6,9,12}$.

The diagnosis of IDA is obtained through measurements of serum iron, total iron-binding capacity (TIBC), transferrin and serum ferritin saturation, whereas the diagnosis of beta TM is usually by hemoglobin electrophoresis and levels of $\mathrm{Hb} \mathrm{A}_{2}$ greater than $3.5 \%$ (Table 1) (5,13 $^{5}$. On the other hand, the diagnosis of alpha TM requires molecular investigations of the alpha gene, since the levels of $\mathrm{Hb} \mathrm{A}_{2}$ are reduced $(<2.5 \%)^{5,7,12}$.

Differentiating IDA, mild or moderate, from TM (alpha and beta) can be a diagnostic dilemma since both conditions are microcytic anemias and share many characteristics. Evidently, a correct diagnosis in patients with microcytic anemia is important: it can provide an indication of iron supplementation for patients with IDA, avoid unnecessary iron therapy for patients with TM, and, of course, prevent severe and lethal forms of thalassemia syndromes through instruction in areas of high prevalence ${ }^{3,8,12}$.

Despite its great usefulness, confirmatory tests for diagnosing microcytic anemias involve methodologies that are time-consuming, high-cost, and inaccessible to poor populations ${ }^{5}$. In an attempt to simplify the differential diagnosis between IDA and TM, more than 40 mathematical indexes based on erythrocyte

TABLE 1. DIFFERENTIAL DIAGNOSIS BETWEEN IRON DEFICIENCY ANEMIA AND BETA THALASSEMIA MINOR13

\begin{tabular}{|c|c|c|}
\hline Variable & $\begin{array}{l}\text { Iron deficiency } \\
\text { anemia }\end{array}$ & $\begin{array}{c}\text { Beta thalassemia } \\
\text { minor }\end{array}$ \\
\hline 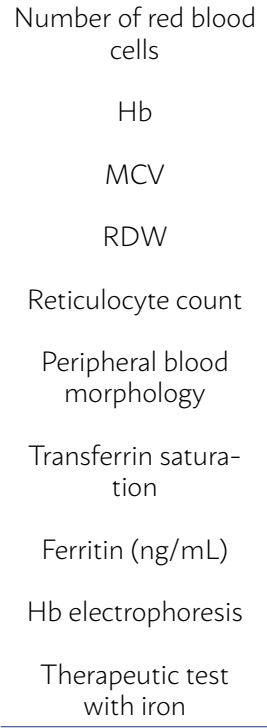 & $\begin{array}{c}\text { dec. } \\
\text { dec. } \\
\text { dec. } \\
\text { inc. } \\
\text { Normal or dec. } \\
\text { Hypochromia } \\
\text { dec. } \\
\text { dec. } \\
\text { Normal Hb } \mathrm{A}_{2} \\
\text { positive }\end{array}$ & $\begin{array}{c}\text { normal or inc. } \\
\text { dec. or normal } \\
\text { dec. } \\
\text { inc. } \\
\text { normal or inc. } \\
\text { microcytosis, } \\
\text { basophilic stippling } \\
\text { normal or inc. } \\
\text { normal or inc. } \\
\text { inc. Hb } \mathrm{A}_{2} . \\
\text { Negative }\end{array}$ \\
\hline
\end{tabular}

Legend: $\mathrm{Hb}$, hemoglobin; MCV, mean corpuscular volume; RDW, red cell distribution width; dec., decreased; inc, increased. parameters have been proposed in the hematologic literature for patients with microcytosis ${ }^{5.8}$. These indexes use formulas that incorporate, in various combinations, at least two erythrocyte parameters provided by automated hematology analyzers. Most indexes incorporate $\mathrm{MCV}, \mathrm{MCH}, \mathrm{RBC}, \mathrm{Hb}$, and RDW, in various combinations, to amplify the differences of unique parameters for both anemias ${ }^{14}$.

England et al. ${ }^{15}$, in 1973, found that RBC alone can differentiate IDA from beta TM. However, in 72 patients with microcytosis, a simple discriminant function derived from MCV, RBC and $\mathrm{Hb}$ (MCV-RBC(5xHb)-3.4) correctly identified all except one of the cases studied (99\%). In another study involving 103 individuals with microcytosis, Mentzer ${ }^{16}$, in 1973, demonstrated that a discriminant function (MCV/RBC) had similar efficacy to that proposed by England et al. ${ }^{15}$. A study conducted by Bessman et al. ${ }^{17}$, in 1979, aiming to quantify the degree of anisocytosis (RDW) in patients with IDA and TM (alpha and beta), showed a marked difference between IDA and TM. Fifty-three individuals with IDA had increased RDW, while 25 with beta TM had normal or slightly increased RDW.

In a study involving 102 patients with IDA and 33 with beta TM, Green \& King ${ }^{18}$, in 1989, compared a new discriminant function $\left(\mathrm{MCV}^{2} \times \mathrm{RDW} / \mathrm{Hbx} 100\right)$ with six other discriminant indexes and concluded that the use of this discriminant function that incorporates RDW resulted in greater accuracy to distinguish IDA from TM. In another study involving 284 patients (130 with IDA and 154 with beta TM), Ehsani et al. ${ }^{19}$, in 2009, compared a new index (MCV-10xRBC) with four other indexes (England-Fraser, Mentzer, Srivastava, and RBC) and demonstrated that the new index was able to identify 263 individuals (92.96\%), inferior only to the Mentzer index, that correctly diagnosed 269 individuals (94.71\%). Despite that, its calculation simplicity makes it acceptable.

More recent studies involving new hematological parameters, such as the percentage of microcytic and hypochromic erythrocytes (M/H ratio), have demonstrated to be useful in detecting small changes in the number of erythrocytes with inadequate hemoglobinization in patients with IDA and $\mathrm{TM}^{20}$.

In a meta-analysis conducted by Hoffmann et al. ${ }^{8}$, in 2015, 12 discriminant indexes were selected from the literature to differentiate between IDA and TM in patients with microcytosis (Table 2). It is widely accepted that none of these indexes is $100 \%$ sensitive and specific. Even more complex approaches, 
TABLE 2. DISCRIMINANT INDEXES (CALCULATIONS, CUT-OFF, SENSITIVITY, AND SPECIFICITY) ${ }^{8}$

\begin{tabular}{|c|c|c|c|c|}
\hline Discriminant indexes & Calculations & Cut-of & Sensitivity & Specificity \\
\hline $\mathrm{M} / \mathrm{H}$ ratio & \% Microcytes/ \% Hypochromic & 3.7 & $0.92(0.87-0.98)$ & $0.86(0.81-0.91)$ \\
\hline RBC & RBC & 5.0 & $0.85(0.80-0.88)$ & $0.90(0.86-0.93)$ \\
\hline Sirdah & $M C V-R B C-(3 \times H b)$ & 27.0 & $0.83(0.75-0.89)$ & $0.90(0.83-0.95)$ \\
\hline Ehsani & $M C V-(10 \times R B C)$ & 15 & $0.91(0.85-0.94)$ & $0.82(0.76-0.87)$ \\
\hline England and Fraser (E\&F) & $M C V-R B C-(5 \times \mathrm{Hb})-3.4$ & 0 & $0.75(0.70-0.79)$ & $0.92(0.90-0.94)$ \\
\hline Green and King (G\&K) & $\mathrm{MCV}^{2} \times \mathrm{RDW} / 100 \times \mathrm{Hb}$ & 65 & $0.79(0.73-0.83)$ & $0.89(0.85-0.92)$ \\
\hline Jayabose (RDW índex) & $M C V /(R B C \times R D W)$ & 220 & $0.83(0.78-0.88)$ & $0.85(0.81-0.88)$ \\
\hline Mentzer & $M C V / R B C$ & 13 & $0.82(0.79-0.86)$ & $0.85(0.82-0.88)$ \\
\hline Shine and Lal (S\&L) & $\mathrm{MCV}^{2} \times \mathrm{MCH}$ & 1.53 & $0.96(0.93-0.97)$ & $0.41(0.27-0.56)$ \\
\hline Ricerca & RDW / RBC & 4.4 & $0.93(0.88-0.97)$ & $0.52(0.36-0.67)$ \\
\hline Srivastava & $\mathrm{MCH} / \mathrm{RBC}$ & 3.8 & $0.78(0.72-0.82)$ & $0.81(0.77-0.85)$ \\
\hline Bessman & RDW & 15 & $0.62(0.61-0.63)$ & $0.66(0.65-0.68)$ \\
\hline
\end{tabular}

including different combinations of simple indexes or multivariate discriminant analysis, are incapable of achieving absolute sensitivity and specificity. However, these indexes can be effective as a preliminary screening tool when an adequate cut-off is chosen ${ }^{8.14}$.

Matos et al. ${ }^{21}$, in 2013, evaluated the discriminative power of seven indexes to differentiate between IDA and beta TM in the Brazilian population and reported that the Green \& King index and RDW had the highest reliability. A study conducted by Miri-Moghaddam et al. ${ }^{9}$, in 2014, to assess the effectiveness of discriminant mathematical formulas and their cut-offs concluded that the Green \& King index had the highest efficiency and suggested that the cut-off should be determined, for all formulas, in different populations. In a large study with 2,664 individuals with microcytic anemia - 1,259 with IDA, 1,196 with TM (877 with beta TM and 319 with alpha TM), 150 with TM with IDA or concomitant chronic disease, and 36 with other diseases, Urrechaga et al. ${ }^{22}$, in 2017, investigated the performance of 25 discriminant indexes that only use parameters available in all automated hematology analyzers and demonstrated that the Green \& King index had an excellent performance, behind only the Jayabose and Janel 11T indexes.

Hoffmann et al. ${ }^{8}$, in 2015, demonstrated that the age group (adult or child) and the geographic region, but not the type of hematological analyzer nor the Cutoff, are important factors to determine the diagnostic usefulness of discriminant indexes. The only situation in which more heterogeneity can be expected is for discriminant indexes that incorporate RDW since this parameter is not well standardized and presents considerable differences between different analyzers.
However, some discriminant indexes that incorporate RDW (Green \& King and Jayabose) combine it with multiple other parameters and, thus, mitigate the possible influence of RDW in their performance ${ }^{22}$.

Overall, the more recent indexes seem to be able to make this distinction better than the more traditional formulas. However, when evaluated in more detail, older indexes (England \& Fraser, Mentzer, and Green \& King) performed better in adults. In contrast, some more recent discriminant indexes (Jayabose, Sirdah, and Ehsani) performed much better in children. The M/H ratio, up until now, has only been investigated in adult populations; therefore, how this discriminant index behaves in children remains to be observed ${ }^{8}$.

Erythrocytosis (increased RBC) and mild anemia are characteristics of $\mathrm{TM}$, and the erythrocytes are usually more microcytic (reduced MCV) than in IDA; whereas in IDA, the level of anisocytosis (RDW) is greater, along with lower Hb levels when compared with those of $\mathrm{TM}^{6,9,12,14}$. According to the meta-analysis conducted by Hoffmann et al. ${ }^{8}$, in 2015, the Green \& King, Jayabose, Ehsani, Sirdah, and RBC indexes had excellent performances, behind only that of the $\mathrm{M} / \mathrm{H}$ ratio (restricted to a few hematologic counters) 20. Based on the superiority of the Green \& King index found in most studies and on its highest performance in adults, along with the high performance of the Ehsani and RBC indexes in children, a simplification is proposed for the differential diagnosis between IDA and TM, based on discriminant indexes (Figure 1).

For patients with beta TM and concomitant IDA, $\mathrm{Hb}$ levels $\mathrm{A}_{2}$ may be reduced, leading to diagnostic difficulties. Therefore, due to the possibility of these 
FIGURE 1. SIMPLIFICATION OF THE DIAGNOSIS OF IRON DEFICIENCY ANEMIA AND THALASSEMIA MINOR, IN ADULTS AND CHILDREN, USING DISCRIMINANT INDEXES.

\section{ADULTS WITH MICROCYTIC ANEMIA}

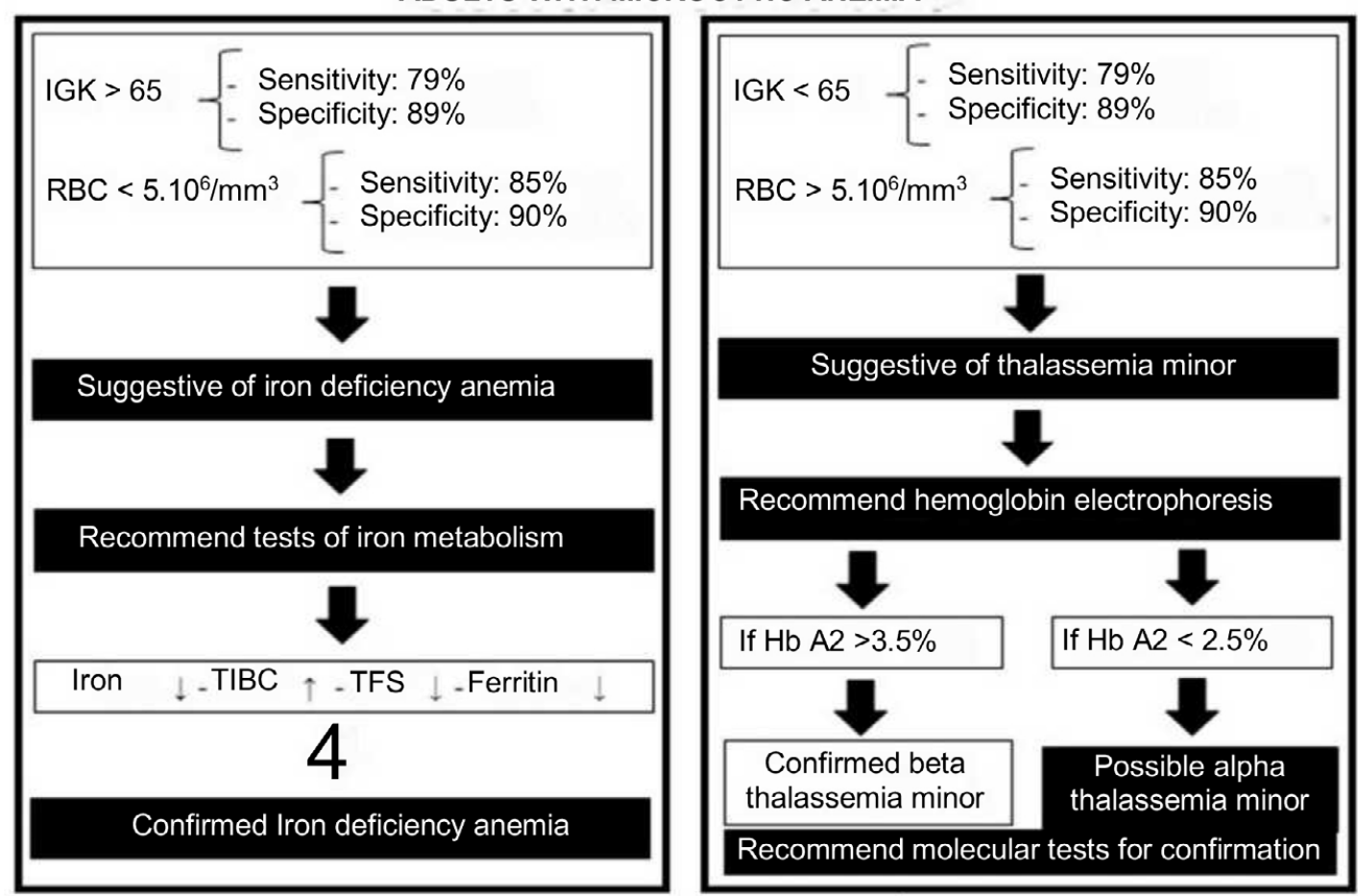

CHILDREN WITH MICROCYTIC ANEMIA
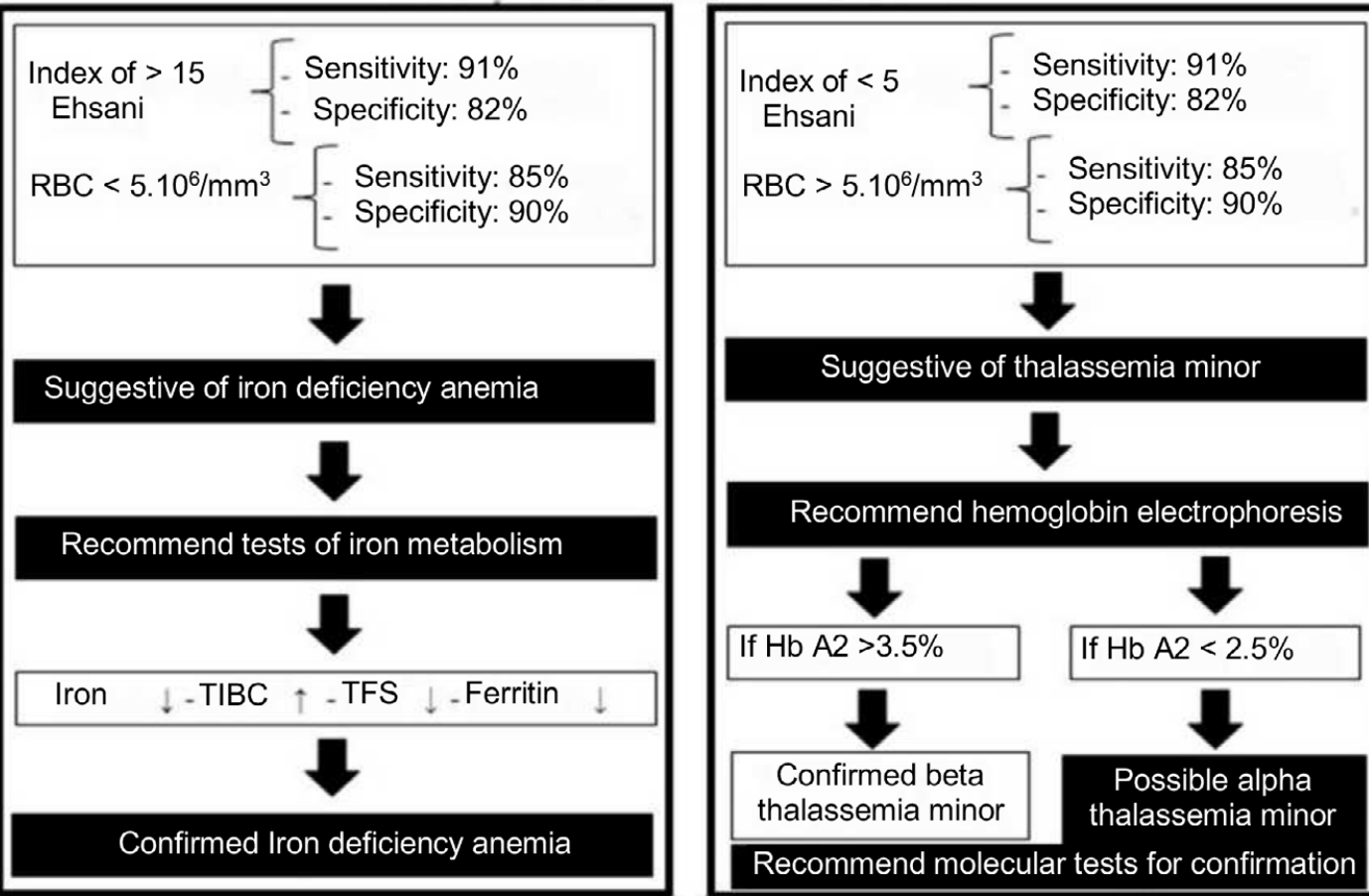

Legend: RBC, Red Blood Cell; Hb, Hemoglobin; MCV, Mean Corpuscular Volume; IGK, Index of Green \& King; TIBC, Total Iron-Binding Capacity; TFS, Transferrin Saturation; Hb A2, Hemoglobin A2. * $\mathrm{Hb}$ and MCV decreased according to age and sex.

two entities coexisting, the diagnosis of beta TM can be confused by reduced levels of $\mathrm{Hb} \mathrm{A}_{2}$ Thus, the iron deficiency must be identified and corrected for patients with a high suspicion of beta TM, particularly if the levels of $\mathrm{Hb} \mathrm{A}_{2}$ are within the normal range (2.5
- 3.5\% $)^{23}$. Another limitation in the use of discriminant indexes is the presence of alpha TM in patients with IDA; thus, individuals with reduced levels of $\mathrm{Hb} \mathrm{A}_{2}$ need to undergo molecular analyses for diagnostic confirmation $^{5.12}$. 


\section{CONCLUSION}

Despite its great usefulness, confirmatory tests for a differential diagnosis between IDA and TM require methods that are time-consuming and costly. In this context, the use of discriminant indexes that use erythrocyte parameters can provide a powerful tool to simplify the diagnosis of IDA and TM. The IGK,
Ehsani, and RBC indexes had excellent performances; however, none of them were sufficiently sensitive and specific to establish a diagnosis. Despite that, they are of great value to identify, in particular, individuals with microcytic anemia, in whom diagnostic tests are indicated for confirmation of TM.

\section{RESUMO}

INTRODUÇão: Anemias microcíticas são muito comuns na prática clínica, sendo a anemia ferropriva (AF) e a talassemia menor (TM) as mais prevalentes. A confirmação diagnóstica dessas entidades clínicas requer testes que envolvem o perfil do metabolismo do ferro, eletroforese de hemoglobinas e análises moleculares. Nesse contexto, vários índices discriminantes têm sido propostos para simplificação do diagnóstico diferencial entre AF e TM.

OBJETIVO: O objetivo deste artigo foi demonstrar a relevância clínica da utilização de índices discriminantes em indivíduos com anemia microcítica, para simplificação do diagnóstico diferencial entre anemia ferropriva e talassemia menor.

MÉTODOS: Foi realizada uma pesquisa bibliográfica e transversal nas bases de dados PubMed, SciELO e Lilacs, utilizando-se os seguintes descritores: anemia ferropriva, talassemia menor e diagnóstico diferencial.

RESULTADOS: Mais de 40 índices matemáticos baseados em parâmetros eritrocitários foram propostos na literatura hematológica em indivíduos com microcitose. Os índices de Green \& King (IGK), o índice de Ehsani e a contagem de eritrócitos (RBC) obtiveram excelentes desempenhos, especialmente quando sua eficácia foi observada em adultos e crianças.

CONCLUSÕES: Testes confirmatórios para o diagnóstico diferencial entre AF e TM demandam métodos que consomem bastante tempo e alto custo. Apesar dos excelentes desempenhos do IGK, do índice de Ehsani e do RBC, nenhum deles possui sensibilidade e especificidade suficientes para firmar diagnóstico. No entanto, podem fornecer uma poderosa ferramenta adicional para simplificação diagnóstica entre AF e TM.

PALAVRAS-CHAVE: Anemia ferropriva. Talassemia beta. Diagnóstico diferencial.

\section{REFERENCES}

1. Tesfaye M, Yemane T, Adisu W, Asres Y, Gedefaw L. Anemia and iron deficiency among school adolescents: burden, severity, and determinant factors in southwest Ethiopia. Adolesc Health Med Ther. 2015;6:189-96.

2. Benoist B, McLean E, Egli I, Cogswell M. Worldwide prevalence of anaemia 1993-2005: World Health Organization global database on anaemia Geneva: World Health Organization; 2008.

3. Carlos AM, Souza BMB, Souza RAV, Resende GAD, Pereira GA, MoraesSouza $\mathrm{H}$. Causes of microcytic anaemia and evaluation of conventional laboratory parameters in the differentiation of erythrocytic microcytosis in blood donors candidates. Hematology. 2018;23(9):705-11.

4. Lei MQ, Sun LF, Luo XS, Yang XY, Yu F, Chen XX, et al. Distinguishing iron deficiency anemia from thalassemia by the red blood cell lifespan with a simple CO breath test: a pilot study. J Breath Res. 2019;13(2):026007.

5. Matos JF, Dusse LM, Borges KB, Castro RL, Coura-Vital W, Carvalho M. A new index to discriminate between iron deficiency anemia and thalassemia trait. Rev Bras Hematol Hemoter. 2016;38(3):214-9.

6. Matos JF, Dusse LMS, Gomes KB, Stubert RVB, Ferreira MFR, Moreira RCN, et al. O hemograma nas anemias microcíticas e hipocrômicas: aspectos diferenciais. J Bras Patol Med Lab. 2012;48(4):255-8.

7. Hafeez Khandro A, Shoombuatong W, Prachayasittikul V, Nuchnoi P. New bioinformatics-based discrimination formulas for differentiation of thalassemia traits from iron deficiency anemia. Lab Med. 2017;48(3):230-7.

8. Hoffmann J), Urrechaga E, Aguirre U. Discriminant indices for distinguishing thalassemia and iron deficiency in patients with microcytic anemia: a meta-analysis. Clin Chem Lab Med. 2015;53(12):1883-94.

9. Miri-Moghaddam E, Sargolzaie N. Cut off determination of discrimination indices in differential diagnosis between iron deficiency anemia and $\beta$-thalassemia minor. Int J Hematol Oncol Stem Cell Res. 2014;8(2):27-32.

10. Matos JF, Dusse LMS, Stubbert RVB, Lages GFG, Carvalho MG. Índice de anisocitose eritrocitária (RDW): diferenciação das anemias microcíticas e hipocrômicas. Rev Bras Hematol Hemoter. 2008;30(2):120-3.

11. Tong L, Kauer J, Wachsmann-Hogiu S, Chu K, Dou H, Smith ZJ. A new red cell index and portable RBC analyzer for screening of iron deficiency and Thalassemia minor in a Chinese population. Sci Rep. 2017;7(1):10510.
12. Belisário AR, Viana MB. Efeitos da talassemia alfa nas manifestações clínicas e hematológicas da anemia falciforme: uma revisão sistemática. Rev Med Minas Gerais. 2010;20(1):312-21.

13. Cançado RD, Chiattone CS. Anemia ferropênica no adulto: causas, diagnóstico e tratamento. Rev Bras Hematol Hemater. 2010;32(3):240-6.

14. Urrechaga E, Borque L, Escanero JF. The role of automated measurement of red cell subpopulations on the Sysmex XE 5000 analyzer in the differential diagnosis of microcytic anemia. Int J Lab Hematol. 2011;33(1):30-6.

15. England IM, Fraser PM. Differentiation of iron deficiency from thalassaemia trait by routine blood-count. Lancet. 1973;1(7801):449-52.

16. Mentzer WC |r. Differentiation of iron deficiency from thalassaemia trait. Lancet. 1973;1(7808):882.

17. Bessman JD, Feinstein DI. Quantitative anisocytosis as a discriminant between iron deficiency and thalassemia minor. Blood. 1979;53(2):288-93.

18. Green R, King R. A new red cell discriminant incorporating volume dispersion for differentiating iron deficiency anemia from thalassemia minor. Blood Cells. 1989;15(3):481-91.

19. Ehsani MA, Shahgholi E, Rahiminejad MS, Seighali F, Rashidi A. A new index for discrimination between iron deficiency anemia and beta-thalassemia minor: results in 284 patients. Pak J Biol Sci. 2009;12(5):473-5.

20. Schoorl M, Schoorl M, Linssen |, Villanueva MM, NoGuera |A, Martinez $\mathrm{PH}$, et al. Efficacy of advanced discriminating algorithms for screening on iron-deficiency anemia and $\beta$-thalassemia trait: a multicenter evaluation. Am J Clin Pathol. 2012;138(2):300-4.

21. Matos JF, Dusse LM, Stubbert RV, Ferreira MR, Coura-Vital W, Fernandes $A P$ et al. Comparison of discriminative indices for iron deficiency anemia and $\beta$ thalassemia trait in a Brazilian population. Hematology. 2013;18(3):169-74.

22. Urrechaga $E$, Hoffman |JML. Critical appraisal of discriminant formulas for distinguishing thalassemia from iron deficiency in patients with microcytic anemia. Clin Chem Lab Med. 2017;55(10):1582-91.

23. Verma S, Gupta R, Kudesia M, Mathur A, Krishan G, Singh S. Coexisting iron deficiency anemia and Beta thalassemia trait: effect of iron therapy on red cell parameters and hemoglobin subtypes. ISRN Hematol. 2014;2014:293216. 